Running Head: NON-CONCATENATIVE MORPHEME SEGMENTATION

Non-Concatenative Morpheme Segmentation in Adults and Children

\author{
Sara Finley ${ }^{\mathrm{a}}$ and Elissa L. Newport ${ }^{\mathrm{b}}$ \\ aPacific Lutheran University \\ ${ }^{\mathrm{b}}$ Georgetown University
}

Acknowledgements: We are grateful to Patricia Reeder, Neil Bardhan, Neil Snider, Carrie Miller, Kelly Johnston, Lily Schieber, Anna States, Emily Kasman, Cristina Flores, Elizabeth Wiemers, and to members of the Aslin-Newport lab. This research was supported in part by NIH grant DC00167 to E. Newport, HD37082 to R. Aslin \& E. Newport, and NIH training grant T32DC000035.

Address correspondence to:

Sara Finley

Department of Psychology

Pacific Lutheran University

12180 Park Ave S

Tacoma, WA 98447

finleysr@plu.edu 


\begin{abstract}
While most morphemes in the world's language involve continuous structure or concatenation (e.g., prefixes and suffixes), many languages show some form of non-adjacent, nonconcatenative morphology. Non-concatenative morphology poses a challenge for statistical learning approaches to morpheme segmentation because the combinatorial possibilities greatly increase for non-adjacent dependencies. The present study explores the types of dependencies that human learners (school-aged children and adults) are able to extract from exposure to a miniature, artificial non-concatenative system. In Experiment 1, participants were exposed to 12 $\mathrm{CCC}$ 'roots' that fit into $72 \mathrm{CVCVC}$ skeletons with a high variety of VV 'residue'. Experiment 2 extended Experiment 1 to school-aged children (with adult controls). Experiment 3 replicated Experiment 1, but with 'mixed' consonant-vowel roots and residues. Across all three experiments, participants were able to recognize familiar items compared to novel items, but had limited ability to generalize the CCC roots to novel items, suggesting a limited ability to parse consonantal roots. Adults were better at generalizing to novel items compared to children.
\end{abstract}




\section{Non-Concatenative Morpheme Segmentation in Adults and Children}

Morphology is the study of the patterns and processes that govern the construction of words. Much research on learning morphology focuses on attaching forms to meanings, such as figuring out which forms of the past tense go with which verbs (Ambridge, 2010; Prasada \& Pinker, 1993; Rumelhart \& McClelland, 1986). Much of this learning relies of parsing concatenative morphology, a process known as morpheme segmentation. Morpheme segmentation involves parsing a word into its roots and affixes (e.g., prefixes and suffixes). However, not all morphological patterns can be segmented in a linear order. In nonconcatenative morphology, morphemes are discontinuous, and roots may never appear in isolation but will always appear in combination with affixation patterns. For example, in Arabic, $k t b$ serves as the consonantal root for 'to write'. To create an inflected form, vowels are added to create a specific word (e.g., kataba 'he wrote', kitab 'a book') (McCarthy, 1981; McCarthy \& Prince, 1990). Non-concatenative morphology interleaves consonants and vowels into patterns of affixes (vowels) and roots (consonants). The question addressed in this paper is whether children and adult learners are able to extract nonadjacent regularities from speech, acquiring a nonconcatenative morphological system.

Insights into how how non-concatenative morphology might be learned may come from research focusing on learning non-adjacent dependencies in phonology and syntax. Nonconcatenative morphology is a form of non-adjacent dependency because the consonantal roots need not be adjacent to each other, and are independent of the vowels that occur between the consonants. Previous research on learning non-adjacent dependencies has typically focused on phonological patterns such as vowel harmony (in which agreement between vowels features applies across syllable boundaries) (Finley, 2011, 2012, 2015b; Finley \& Badecker, 2009; Martin 
\& White, 2020), word segmentation (Frost \& Monaghan, 2016; Misyak et al., 2009; Newport \& Aslin, 2004; Toro et al., 2008), and syntactic regularities (Gomez, 2002; Gomez \& Maye, 2005; Misyak et al., 2009; Misyak \& Christiansen, 2007). These studies have shown that while there are biases towards adjacent dependencies over non-adjacent dependencies, learners can overcome the biases with sufficient statistical, grammatical, and attentional cues (Wilson et al., 2020).

Studies focusing on non-adjacent dependencies in morphology and morpheme segmentation have also shown a bias towards concatenative over non-concatenative morphology (Drake, 2018; Fullwood, 2018; Fullwood \& O’Donnell, 2013), likely due to the non-adjacent dependencies that non-concatenative morphology relies upon. Non-adjacent dependencies pose a challenge for a statistical learner. Computing both adjacent and non-adjacent dependencies creates a potential for computational explosion. For example, in the word [kitab], there are only $4 *(n-1)$ adjacent dependencies between bigrams: [ki], [it], [ta], [ab]. Adding non-adjacent dependencies involves 10*(n(n+1)/2) dependencies: [ki], [kt], [ka], [kb], [it], [ib], [ia], [ib], [ta], [tb], [ab] (Fullwood, 2018). Increasing the size of the dependencies (e.g., to trigrams) only increases the computational complexity, posing a challenge for a learner relying on statistics alone.

Two main hypotheses have emerged for how a statistical learner could compute nonadjacent dependencies. First, similarity between the non-adjacent elements and dissimilarity between the adjacent elements can guide the learner for what to look for. In language, consonants and vowels can serve this purpose. Consonants and vowels have different acoustic characteristics, and play different roles in the phonology of the language. Thus, if learners extract statistical regularities over vowels, skipping consonants (or vice versa), the computational 
problem becomes much easier. This is precisely what occurs in vowel and consonant harmony, a phonological pattern that requires vowels (in vowel harmony) or consonants (in consonant harmony) to share the same phonological feature within a domain (e.g., word). In languages with vowel harmony, consonants have minimal influence on the quality of vowels; harmony between consonants 'skips' consonants. The ability for vowels to influence each other with intervening consonants (and likewise for consonants) across a variety of linguistic processes has lead phonologists to propose that vowels and consonants exist on separate 'tiers' of representation (Clements, 1985; Goldsmith, 1976). This means that the word [katab] contains a vowel tier with [aa] and a consonant tier with [ktb]. In this representation $[\mathrm{k}]$ and $[\mathrm{t}]$ are adjacent. For [katab], if non-adjacent dependencies are counted only through elements of the same class (consonants and vowels), then the number of possible dependencies reduces significantly (e.g., [kt], [tb], [ia]) thereby reducing the learning problem (Heinz, 2010).

The use of vowel and consonant tiers also serves a purpose in non-concatenative morphology. In non-concatenative morphology, consonants serve as the 'roots' and vowels often serve as the 'pattern', that fit into a CV (C for consonant, V for vowel) templatic structure. Newport and Aslin (2004) showed that learners could only extract non-adjacent dependencies from an un-segmented stream of speech when the dependencies were based on consonants (e.g., /ptk/ fitting into a template to create /patuke/) rather than based on syllables (e.g., /pa_ke,/ where any syllable can go between $/ \mathrm{pa} /$ and $/ \mathrm{ke} /$ ).

The separate roles of consonants and vowels in non-concatenative morphology could ease the burden of the learner, and reduce the computational complexity of the learning problem. Previous research has suggested that learnability of non-adjacent dependencies in phonology may require parsing vowels and consonants on different tiers (Burness \& McMullin, 2019; 
Chandlee, 2014; Heinz, 2010; McMullin, 2016; Newport \& Aslin, 2004), and that learners show biases against root and pattern morphology with roots that contain a mix of consonants and vowels (Fullwood, 2018).

Another hypothesis for how learners are able to cope with non-adjacent dependencies is the variability of the adjacent elements compared to the non-adjacent elements. Gomez (2002) showed that dependencies between two non-adjacent words could only be learned when the variation between the adjacent elements and the non-adjacent elements was sufficiently high. For example, in learning a rule ' $1 \mathrm{~A} 2$ ', where 2 follows 1 after some element $\mathrm{A}$, the dependency between 1 and 2 is only learned when the number of elements in A is sufficiently large. The idea is that the learner extracts the regularity ( 1 and 2 ) out of the variability (A), so A needs to be large in order to appear variable.

These two hypotheses are addressed in the present study. First, we ask whether the use of variation as a cue to learn non-concatenative morphology applies to both children and adults. Second, we test whether the learnability of non-concatenative morphology relies on separate roles for consonants and vowels. In Experiment 1, the learnability of root and pattern morphology is assessed when adult, English speaking participants were exposed to words from a CVCVC language with $12 \mathrm{CCC}$ roots, and a large variety of vowel patterns.

Experiment 2 replicates Experiment 1 using a paradigm appropriate for child learners, and compares the performance of school-aged children with adult controls. In Experiment 3, we exposed participants to words from a CVCVC language with roots that contained a mix of consonants and vowels; $12 \mathrm{CCV}$ 'roots' were interleaved with a highly variable VC residue. If learners rely on the differing roles of consonants and vowels to parse non-concatenative morphology, then it is expected that participants in Experiment 3 will not be able to learn the 
$\mathrm{CCV}$ roots from a similar exposure to CVCVC words found in Experiments 1 and 2 with CCC roots and vowel residues.

\section{Experiment 1}

Experiment 1 explores the learnability of non-adjacent dependencies in morpheme segmentation. Adult, English speaking participants were exposed to a miniature language with a root and pattern morphology system with $12 \mathrm{CCC}$ consonantal roots that fit into a CVCVC template, where the vowels were highly variable. Participants were tested on their ability to segment the consonantal roots using a two-alternative forced choice task that compared learners' ability to differentiate between words that fit the non-concatenative pattern, and words that did not.

\section{Method}

\section{Participants}

All participants were adult monolingual native English speakers. Twenty-five participants were recruited from the University of Rochester community. All participants were paid \$10 for their participation. Participants were randomly assigned to one of two languages (A and B), with 12 participants in Language A, and 13 participants in Language B.

\section{Design and Materials}

Experiment 1 was designed so that the variation of the consonant patterns was smaller than the variation of the vowel patterns. All participants were randomly assigned to one of two miniature languages (Language $A$ and Language $B$ ), made from sets of $72 C_{1} V_{A} C_{2} V_{B} C_{3}$ words repeated five times each. The words from each language were formed from the same rules, described below, but with varying vowel and consonant patterns. Use of two languages helps to control for random idiosyncrasies in the sound patterns that may inadvertently affect learning. 
Care was taken so that each consonant and vowel appeared equally often in each position, and that all the words were potential English words, but no CVCVC form was an actual English lexical item.

The training set consisted of 72 words: the 12 consonantal roots paired with six (of 30 or 34 possible) vowel residues $(12 \times 6=72)$. Each of the $72 \mathrm{C}_{1} \mathrm{~V}_{\mathrm{A}} \mathrm{C}_{2} \mathrm{~V}_{\mathrm{B}} \mathrm{C}_{3}$ words (where the subscripts 1,2, and 3 are given to indicate the order of the consonants heard in the training items, and the subscripts A and B are given to indicate the order of the vowels heard in training) was composed of a CCC root with VV residue that fit into the CVCVC template. The 12 consonantal (CCC) roots were made of three consonants from the set /p, t, k, b, d, g, f, s, z, v/, such as /ptk/, /bdg/ and /ftk/, with the rule that no two consonants could be in the same root (e.g., */ptp/ was not permitted). The vowel patterns were created from the set $[\mathrm{a}, \mathrm{e}, \mathrm{i}, \mathrm{o}, \mathrm{u}, \mathfrak{x}, \varepsilon, \Lambda, \mathrm{I}]$ (to fill the $\mathrm{C}_{1} \mathrm{~V}_{\mathrm{A}} \mathrm{C}_{2} \mathrm{~V}_{\mathrm{B}} \mathrm{C}_{3}$ template). Four of the vowel patterns ('frequent') appeared with four of the 12 consonantal roots; each CCC root was paired with 2 'frequent' vowel pairs. The remaining 'infrequent' vowel patterns were distributed among the CCC roots as evenly as possible. There were 30 total vowel residues in Language A and 34 vowel residues in Language B. Examples of training items can be found in Table $1^{1}$.

\section{INSERT TABLE 1 ABOUT HERE}

Learnability $^{2}$ of the miniature language was assessed with a two-alternative forced-choice test that contained five different types of test items (eight of each). The first test type, referred to as Old:Scrambled items, required participants to choose between words that were heard in

\footnotetext{
${ }^{1}$ Full stimuli lists can be found in the Appendix; stimuli files, analysis code and other materials can be found at: https://osf.io/3akfg/

${ }^{22}$ The test items in Experiment 1 were identical to those in another set of experiments from Finley and Newport (2020). For this reason, there is duplication in the writing of this Method section, as it is not possible to write the same methodology using completely different words.
} 
training, and an ungrammatical word that was created by reversing the final two consonants of a word heard in training (e.g., /bidig/ vs. *3/bigid/, $C_{1} V_{A} C_{2} V_{B} C_{3}$ vs. $C_{1} V_{A} C_{3} V_{B} C_{2}$ ). Because one can choose the correct item simply through memorization, it is predicted that participants should perform above chance on these items.

The other four types of test items probed whether participants can generalize the CCC roots to one of the word combinations formed by the consonantal root and vowel patterns that are possible (i.e., grammatical) but were not heard in training. New:Scrambled(Hard) test items, were of the same format as Old:Scrambled items, except that the 'correct' (grammatical) item was not heard in training. Instead, the grammatical item consisted of consonants and vowels that had appeared in training but not in the same word (e.g., /badug/vs.*/bigad/, $\mathrm{C}_{1} \mathrm{~V}_{\mathrm{X}} \mathrm{C}_{2} \mathrm{~V}_{\mathrm{Y}} \mathrm{C}_{3}$ vs. $\mathrm{C}_{1} \mathrm{~V}_{\mathrm{A}} \mathrm{C}_{3} \mathrm{~V}_{\mathrm{B}} \mathrm{C}_{2}$, where the subscripts $\mathrm{X}$ and $\mathrm{Y}$ refer to a vowel pattern heard in training but was not paired with the specific CCC consonantal root). These New:Scrambled items are considered 'hard' because the scrambled item preserves the first syllable $\mathrm{C}_{1} \mathrm{~V}_{\mathrm{A}}$ of the familiar item. Thus, the first syllable in the ungrammatical item will be familiar to participants, but the first syllable in the grammatical, novel item will be unfamiliar. For this reason, we created a third set of items, referred to as New-Scrambled(Easy) items, which compared a grammatical novel item (1X2Y3, as in New-Scrambled(Hard) items) to an ungrammatical item that was created by rearranging all three consonants of a word heard in training (e.g., /dizag/vs.*/gudiz, $\mathrm{C}_{1} \mathrm{~V}_{\mathrm{X}} \mathrm{C}_{2} \mathrm{~V}_{\mathrm{Y}} \mathrm{C}_{3}$ vs. $\left.\mathrm{C}_{3} \mathrm{~V}_{\mathrm{A}} \mathrm{C}_{1} \mathrm{~V}_{\mathrm{B}} \mathrm{C}_{2}\right)$.

The fourth type of test item probed whether participants learned that the order of the consonantal roots was specific to the $\mathrm{CCC}$ root, rather than a more general phonotactic constraint (e.g., if exposed to /patak/ that they learned that $[\mathrm{p}],[\mathrm{t}]$ and $[\mathrm{k}]$ may appear together, in that

3 '*' indicates an ill-formed, or ungrammatical word. 
order, rather than just that words may start with $[\mathrm{p}])$. These items pitted a novel, but grammatical item $\left(\mathrm{C}_{1} \mathrm{~V}_{\mathrm{X}} \mathrm{C}_{2} \mathrm{~V}_{\mathrm{Y}} \mathrm{C}_{3}\right)$ with an ungrammatical nonword that was created by taking the first consonant from one consonantal root, and the final two consonants from a different consonantal root, referred to as a nonword hybrid. These items were referred to as New:NonWord Hybrid $(\mathrm{NWH})$ items $\left(\mathrm{C}_{1} \mathrm{~V}_{\mathrm{A}}\right)\left(\mathrm{C}_{2} \mathrm{~V}_{\mathrm{B}} \mathrm{C}\right)^{4}$. If participants learned the consonantal root, participants will select the novel item significantly above chance, but if participants parse the training items as syllables, rather than as non-continuous CCC roots, then participants will prefer the NonWord Hybrid (NWH) items.

One way to test for abstract representations is to compare whether learners can differentiate between familiar and novel grammatical items. This fifth set of test items, referred to as Old-New items, compared familiar items $\left(\mathrm{C}_{1} \mathrm{~V}_{\mathrm{A}} \mathrm{C}_{2} \mathrm{~V}_{\mathrm{B}} \mathrm{C}_{3}\right)$ with a novel item $\left(\mathrm{C}_{1} \mathrm{~V}_{\mathrm{X}} \mathrm{C}_{2} \mathrm{~V}_{\mathrm{Y}} \mathrm{C}_{3}\right)$. These items were coded as 'correct' when the participant selected the Old item, even though both items are grammatical. Failure to score above chance on these items suggests that learners have formed an abstract grammar, as participants find novel and familiar items equally acceptable. Examples of test items can be found in Table 2.

\section{INSERT TABLE 2 ABOUT HERE}

All stimuli were recorded in a sound-attenuated booth by an adult female native English speaker. While the speaker was aware that the stimuli were to be used for an artificial grammar learning study, the speaker was unaware of the hypothesis of the study. Tokens were individually recorded. Each token was spoken four times in list format. A single token was chosen from the second or third element of the set in order to keep the prosody as uniform as possible (e.g., avoid the intonation of first and last elements in a list). The speaker was told to speak each word as

\footnotetext{
${ }^{4}$ Due to experimenter error, two of the nonword hybrid items in Language B did not conform to the structure presented here, and were therefore removed from analysis.
} 
clearly and accurately as possible (without reducing vowels). Stress was placed on the final syllable. All stimuli were normalized to $70 \mathrm{~dB}$.

\section{Procedure}

Participants were told that they would be listening to words from a language that they had never heard before, and that their task was to listen to the way the novel language sounded, but that they need not try and memorize the forms. The training consisted of 72 tri-syllabic items repeated five times each. The training was followed by the 40 -item two-alternative forced-choice test described above. Participants were told that they would hear two words, one belonging to the language they heard, and the other not belonging to the language. If they believed the first word belonged to the language, they were to press the 'a' key; if they believed the second word belonged to the language, they were to press the ' 1 ' key. Participants were told to respond as quickly and accurately as possible, but no time limit was given for responses. The experiment took approximately 24 minutes to complete.

\section{Results}

Results (means and standard errors) from Experiment 1 can be found in Figure 1. All data were entered into generalized mixed effects models using the glmer function in the lme4 package (Bates et al., 2015) in R (R Development Core Team, 2018) through RStudio (RStudio Team, 2020) with the maximal model that would converge, as justified by the experimental design (Barr et al., 2013). This included random intercepts for items and subjects ${ }^{5}$. To test whether each of the five test items were significantly different from chance, a separate model was run with the relevant test item set as the baseline, with a significant intercept interpreted as a significant difference from chance.

\footnotetext{
${ }^{5}$ Several models received singular fit warnings. When the structure of the model was reduced, the warnings, and the results were generally identical or very similar to the more complex model.
} 


\section{INSERT FIGURE 1 ABOUT HERE}

We compared the overall correct responses to Language A with the responses to Language $\mathrm{B}$, and found no significant differences between Language $\mathrm{A}$ and $\mathrm{B}, \beta=0.039, S E=$ $0.26, z=0.15, p=0.88$. For this reason, we combined responses between Language A and B for all analyses.

Correct responses to Old:Scrambled $\left(\mathrm{C}_{1} \mathrm{~V}_{\mathrm{A}} \mathrm{C}_{2} \mathrm{~V}_{\mathrm{B}} \mathrm{C}_{3}\right.$ vs. $\left.\mathrm{C}_{1} \mathrm{~V}_{\mathrm{A}} \mathrm{C}_{3} \mathrm{~V}_{\mathrm{B}} \mathrm{C}_{2}\right)$ items, with a mean of $0.71, C I \pm 0.063$, were selected at a rate significantly above chance, $\beta=1.00, S E=0.24, z=$ 4.19, $p<0.001$. Correct responses to New:Scrambled(Easy) $\left(\mathrm{C}_{1} \mathrm{~V}_{\mathrm{X}} \mathrm{C}_{2} \mathrm{~V}_{\mathrm{Y}} \mathrm{C}_{3} \quad \mathrm{vs} \mathrm{C}_{3} \mathrm{~V}_{\mathrm{A}} \mathrm{C}_{1} \mathrm{~V}_{\mathrm{B}} \mathrm{C}_{2}\right)$ items, with a mean of $0.665, C I \pm 0.066$ were selected at a rate significantly above chance, $\beta=$ 0.76, $S E=0.23, z=3.27, p=0.0011$. Correct responses to New:Scrambled(Hard) items $\left(\mathrm{C}_{1} \mathrm{~V}_{\mathrm{X}} \mathrm{C}_{2} \mathrm{~V}_{\mathrm{Y}} \mathrm{C}\right.$ vs. $\left.\mathrm{C}_{1} \mathrm{~V}_{\mathrm{A}} \mathrm{C}_{3} \mathrm{~V}_{\mathrm{B}} \mathrm{C}_{2}\right)$, with a mean of $0.59, C I \pm 0.069$, were selected at a rate that was only marginally above chance, $\beta=0.40, S E=0.23, z=1.74, p=0.0825$. These results suggest that participants were able to parse the non-concatenative morphology. This is likely to represent abstract learning as correct responses to Old:New $\left(\mathrm{C}_{1} \mathrm{~V}_{\mathrm{A}} \mathrm{C}_{2} \mathrm{~V}_{\mathrm{B}} \mathrm{C}_{3}\right.$ vs. $\left.\mathrm{C}_{1} \mathrm{~V}_{\mathrm{X}} \mathrm{C}_{2} \mathrm{~V}_{\mathrm{Y}} \mathrm{C}_{3}\right)$ items, with a mean of $0.565, C I \pm 0.069$ were not selected at a rate significantly above chance, $\beta=0.30, S E=$ $0.23, z=1.19, p=0.23$. However, correct responses to New:NonWord Hybrid (NWH) items $\left(\mathrm{C}_{1} \mathrm{~V}_{\mathrm{X}} \mathrm{C}_{2} \mathrm{~V}_{\mathrm{Y}} \mathrm{C}_{3}\right.$ Vs. $\left.\left(\mathrm{C}_{1} \mathrm{~V}\right)\left(\mathrm{C}_{2} \mathrm{VC}_{3}\right)\right)$ with a mean of $0.56, C I \pm 0.074$, were not selected at a rate significantly above chance, $\beta=0.29, S E=0.24, z=1.19, p=0.23$, suggesting that participants were unable to differentiate between a syllabic parse and a CCC parse.

To further investigate whether participants were able to recognize novel items, we compared responses to Old:New items to each of the other four test conditions via pairwise comparisons. There were significantly more correct responses to Old:New items compared to Old:Scrambled items, $\beta=0.70, S E=0.31, z=2.265, p=0.024$, but no significant differences 
between and Old:New and New:Scrambled(Hard) items, $\beta=0.098, S E=0.30, z=0.33, p=0.74$, New:Scrambled(Easy) items, $\beta=0.46, S E=0.30, z=1.52, p=0.13$, or New:NonWord Hybrid items, $\beta=0.0088, S E=0.31, z=0.028, p=0.98$.

\section{Discussion}

Participants selected the 'correct' response at a rate significantly above chance for the Old:Scrambled, New:Scrambled(Easy) items. This suggests that participants were able to recognize both familiar and novel items, compared to ungrammatical items. However, participants did not successfully select the correct response at a rate greater than chance for the New:NonWordHybrid items, and were only marginally above chance for but only marginally so for the New:Scrambled(Hard) items, which tested participants' ability to distinguish between novel items and familiar items with the consonants in the second syllable switched. This suggests that learners were only able to differentiate novel grammatical items from ungrammatical items when the ungrammatical item was sufficiently different from the grammatical item. As noted above, the ungrammatical option in these items are highly similar to grammatical items, which may have made it more difficult for participants to differentiate between the grammatical and ungrammatical items. In addition, the grammatical and ungrammatical items often differed by only a single phonological feature (e.g., voicing, place of articulation, manner of articulation), thus increasing the confusability between the grammatical and the ungrammatical items. Because many of the consonant roots in the training set in Language A differed by only a single switched consonant (dgv and dzg; kpt and kts; tfp and tps), it is possible that these small differences for consonantal roots created some confusability that made it difficult for learners to recognize the subtle differences between the new and the scrambled old items.

The failure to differentiate between Old and New items at a rate significantly above 
chance could be due either to learners making use of an abstract rule, or due to using similarity to known structures. Since novel grammatical and familiar items are very similar to each other, participants may not have been able to distinguish these items at a rate greater than chance.

The results of Experiment 1 suggest that it is possible to form associations between nonadjacent consonantal roots without any reference to semantics, when there were only 12 consonantal 'roots' with a large number of vowel patterns. Learners are capable of finding nonadjacent regularities following limited exposure to these novel words. However, this ability may be limited, as the correct responses to novel items were only significantly above chance when they were compared to familiar items, or when the ungrammatical items were highly similar to the familiar items.

It is important, however, to determine whether children, when exposed to a root-andpattern language, may fare better or worse than the adults in Experiment 1. While children show limited memory and attentional capacity compared to adults, children, still in the critical period for language, may have a better ability to find regularities in their language input. Children's limited memory and attentional capacity may actually help children find regularities that are harder for adults to discover (Hudson Kam \& Newport, 2005, 2009; Newport, 1990). Experiment 2 compares the ability to extract consonantal roots from CVCVC templates between children and adults.

There are several reasons that adults may fare differently than children on a short-term learning task. First, adults have a larger attention span, and working memory capacity compared to children. This means that adult learners can remember more of the materials heard at training, and attend to the learning task longer than children. This greater memory and attentional capacity may make adult learners more likely to use different learning strategies than children (Hudson 
Kam \& Newport, 2005, 2009; Samara \& Caravolas, 2014; Thiessen, 2010). Second, adult participants may be more savvy about the experimental design, and be more likely to actively search for patterns in the language set, and use strategies that are not part of the general language learning mechanism. However, children are known to be regular language learners, and may be more likely to extract grammatical regularities than adults (Hudson Kam \& Newport, 2005, 2009). Experiment 2 tests whether child and adult learners differ on their ability to parse nonconcatenative morphology from distributional cues.

\section{Experiment 2}

The goal of Experiment 2 was to compare child and adult learners' ability to extract regularities form root and pattern morphology when there are a relatively small number of patterns. Experiment 2 replicates Experiment 1 with school-aged children (compared to adult controls) using a modified exposure set and presentation design.

\section{Method}

\section{Participants}

There were 23 child participants in the present study, with ages ranging from $7-10$. All children were native English speakers recruited at afterschool daycare programs in Rochester, NW, Elmhurst, IL, and Forest City, IA. The children gave both written and verbal assent following written parental permission. All children received a small bag of toys as a token of appreciation for their participation. The same procedure was also performed on 17 adult participants who served as controls for comparison. The adult control participants were students at a small liberal arts college in Northern Iowa, who received extra credit for their participation. These students were native English speakers, with minimal knowledge of a non-concatenative 
language. The participants did not participate in Experiment 1, or any other grammar learning experiments that exposed participants to morphological rules.

\section{Design and Materials}

The design of the CVCVC languages used in Experiment 2 were identical to Experiment 1. However, to make the task suitable for children, the exposure phase was reduced so that the participants only heard the training set twice, and participants were required to repeat each word aloud before moving on to the next item in the training set. The test phase was also shortened by removing Old:New and New:Scrambled(Hard) test items. Additional changes to the general procedure are discussed below.

\section{Procedure}

The exposure phase was modified from to Experiment 1 in order to make it more suitable for children, based on the procedure used in Finley and Newport (2011). Participants were told that they would be learning an alien language called 'Silly Speak'. Participants were asked to repeat words from the language in order to see pictures of the aliens, referred to as 'Silly People'. Every time the participant repeated a word, a picture of a 'Silly Person' appeared, as shown in Figure 2. The Silly People were assigned at random, so there were no semantic associations between the word heard and the person seen.

\section{INSERT FIGURE 2 ABOUT HERE}

After 36 trials, the participant placed a sticker next to a picture of a Silly Person on paper. Once the participant repeated each word in the exposure set two times (to collect all four stickers), the participant proceeded to the 'Silly Guessing Game', which was the same twoalternative forced choice test as in Experiment 1, except that the participant was instructed that they would hear two words, one word from Silly Speak, and another word not from Silly Speak 
('Wacky Speak'). The participant's job was to guess as best they could which word was from Silly Speak.

\section{Results}

Data (means and standard errors) for Experiment 2 are presented in Figure 3, and were analyzed in the same manner as Experiment 1.

\section{INSERT FIGURE 3 ABOUT HERE}

\section{Child Results}

We first compared Language A and B to each other via a mixed effects model with random intercepts for subjects, items, and test condition. There were no overall differences between Languages $\mathrm{A}$ and $\mathrm{B}, \beta=0.017, S E=0.36, z=0.065, p=0.95$, and were therefore combined in further analyses.

The child participants were showed correct responses that were significantly higher than chance for the Old:Scrambled items, mean $=0.65, C I \pm 0.070, \beta=0.66, S E=0.19, z=3.52, p<$ 0.001, and New:NonWord Hybrid Items, mean $=0.62, C I \pm 0.11, \beta=0.61, S E=0.20, z=3.09, p$ $=0.0020$, but did not select the correct response significantly more often than chance for the New:Scrambled(Easy) items, with a mean of $0.51, C I \pm 0.075, \beta=0.046, S E=0.18, z=0.26, p$ $=0.80$.

Pairwise comparisons showed that there were significantly more correct responses to Old:Scrambled items than New:Scrambled(Easy) items, $\beta=0.61, S E=0.23, z=2.65, p=$ 0.0080, but that there were no significant differences between correct responses to Old:Scrambled and New:NonWord Hybrid items, $\beta=0.050, S E=0.24, z=.21, p=0.84$. This suggests that child participants could only generalize to novel items when compared to 
ungrammatical items that a set of three consonants that did not appear in any single training word.

\section{Adult Results}

We first compared Language A and B to each other via a mixed effects model with random intercepts for subjects, and items. There were no overall differences between Languages $\mathrm{A}$ and $\mathrm{B}, \beta=0.47, S E=0.35, z=1.35, p=0.18$, and were therefore combined in further analyses.

The adult participants selected the correct response at a rate higher than chance for all three types of test items: Old:Scrambled items, with a mean of $0.725, C I \pm 0.081, \beta=1.08, S E=$ $0.29, z=3.74, p<0.001$, New:NonWord Hybrid items, with a mean of 0.67, $C I \pm 0.092, \beta=$ $0.80, S E=0.30, z=2.70, p=0.0070$, and New:Scrambled(Consonant) items, with a mean of $0.64, \mathrm{CI} \pm 0.087, \beta=0.66, S E=0.28, z=2.40, p=0.017$. This suggests that participants successfully learned to parse the non-concatenative language.

Pairwise comparisons showed that the proportion of correct responses to Old:Scrambled items was not significantly different than New:Scrambled(Consonant) items, $\beta=0.41, S E=$ $0.38, z=1.10, p=0.27$, or New:NonWord Hybrid items, $\beta=0.28, S E=0.39, z=.71, p=0.48$. This suggests that the adults were able to learn the consonantal roots in the non-concatenative pattern, and that there was no particular bias towards familiar (Old) items at test.

\section{Children vs. Adult Participants}

We first compared Language A and B to each other via a mixed effects model with random intercepts for subjects, items and age. There were no overall differences between Languages $\mathrm{A}$ and $\mathrm{B}, \beta=0.18, S E=0.23, z=0.78, p=0.44$, and were therefore combined in further analyses. 
Pairwise comparisons showed no significant differences in correct responses between children and adults for New:NonWord Hybrid items, $\beta=0.14, S E=0.31, z=0.45, p=0.65$, or Old:Scrambled items, $\beta=0.36, S E=0.29, z=1.21, p=0.23$, but Adults were more likely to select the correct response to New:Scrambled(Easy) items than Children, $\beta=0.57, S E=0.28, z=$ 2.04, $p=0.042$. These results are in line with the results reported for each age group, as child participants did not select the correct response to New:Scrambled(Easy) items at a rate greater than chance, but adult participants did.

\section{Discussion}

Experiment 2 demonstrated that both children and adults can learn non-concatenative morphology with minimal exposure. While children performed successfully on Old:Scrambled and New:NonWord Hybrid items, they were not successful at New:Scrambled(Easy) items. However, the adults were successful on all three types of test items, and significantly better than children at the New:Scrambled(Easy) items. Children in Experiment 2 were unable to distinguish between novel and scrambled items, which may be a reflection of their phonological development, since the scrambled items were highly similar to the exposure items. Participants in Experiment 2 were only exposed to the 72 item training set twice, which may have made it difficult for child participants to fully remember the exact order of all of the consonant roots.

Both child and adult participants in Experiment 2 successfully selected the correct response for New:NonWordHybrid items at a rate greater than chance, but this was not shown in Experiment 1. It is unclear how to interpret this difference between experiments. One possibility could be an issue of statistical power, as the mean responses to the New:NonWordHybrid items were above $55 \%$ in Experiment 1 . Another possibility could be that repeating the items in Experiment 2 may have helped learn the sound patterns better, even though there was limited 
exposure. Since repetition is an active task, it could have ensured that participants held their attention and attended to the sounds of the words, while a passive listening task (in Experiment 1) might have made it easier to 'zone out' or not attend to the sounds of the words, resulting in more variation in responses.

Experiments 1-2 demonstrated that high variability of vowels compared to consonants helped adults and children learn some aspects of non-concatenative consonant roots without semantic information. A large number of vowel pairs created enough variability to draw attention to the regularities of the consonant patterns in Experiments 1-2. In all cases, the roots were consonantal and the vowels were the 'residue'. Having a separate role for vowels and consonants may have made learning regularities easier. In languages with root and pattern morphology, the roots are typically consonantal, with vowel residues based on a templatic structure (McCarthy, 1981). Almost all cases of root and pattern morphology have a clear differentiation between consonants and vowels.

The distinction between consonant and vowels fits well with hierarchical models of distinctive features (e.g., Goldsmith, 1975), and fit well with generative models of phonological phenomena. Allowing for different roles of consonants and vowels could also ease the computational complexity associated with learning, both in terms of assigning different grammatical functions in early language development (Bonatti et al., 2005, 2007; Mehler et al., 2006; Toro et al., 2008), as well as different representational properties (Heinz, 2010). For example, Newport and Aslin (2004) showed that learners were able to segment speech with nonadjacent dependencies at the segment (consonant) level, but not at the syllable level. Computational models of learning phonological patterns such as vowel and consonant harmony also rely on tier-based separation of features (Heinz, 2010). 
Thus, it is possible that while the ability to parse non-concatenative morphology was limited in Experiments 1-2, that this ability may be even more impaired if the dependencies were based on a mix of consonants and vowels, rather than on consonantal roots. Fullwood (2018) found a bias against mixed consonantal-vowel roots, suggesting that learners may be biased towards consonantal roots. The present study complements this research by exploring what patterns are extracted from CVCVC words with CCV 'roots' and VC 'patterns'.

\section{Experiment 3}

Experiment 3 explores the question of whether the ability to parse non-concatenative morphology is affected by the fact that the patterns in previous studies (and natural languages) were within consonants (rather than a mixture of consonants and vowels) using an artificial language where the CVCVC templates are filled with patterns that mix consonants and vowels.

\section{Method}

\section{Participants}

All participants were adult monolingual native English speakers. Sixteen participants were recruited from the University of Rochester community. All participants were paid $\$ 10$ for their participation. Participants were randomly assigned to one of two languages (A and B), with 8 participants in each group.

\section{Design}

Experiment 3 was designed to test whether learnability of templatic morphology relies on separating vowels from consonants. In the present experiment CVCVC templates were filled in with CCV 'roots' and VC 'patterns'. Participants were tested on their ability to learn the CCV roots.

\section{Materials}


Participants were exposed to a CVCVC templatic language with 72 CVCVC items created out of $12 \mathrm{CCV}$ 'roots'. The VC residues were created such that 24 items were made of six tokens from four frequent patterns (/ok/, /em/, /it/, and /ub/ for Language A, and /op/, /ed/, /iv/, and /ut/ for Language B), with 48 items made from infrequent patterns. Participants heard each of the 72 items five times, repeated in a different random order each time.

The two-alternative forced choice test consisted of 32 items from four different types of test items: Old:Scrambled, New:Scrambled(Easy), Old-New, and New:NonWordHybrid. The Scrambled items were created by reversing the order of the two consonants in the CCV roots, and switching the order of the two vowels in the old word (e.g., /sfi/ in [sofik] became [fisok]). For this reason, there was only one type of New:Scrambled item.

\section{Procedure}

The procedure was identical to Experiment 1.

\section{Results}

Means and standard errors of the mean for Experiment 3 can be found in Figure 4, below. The data for Experiment 3 were analyzed in the same manner as Experiment 1.

\section{INSERT FIGURE 4 ABOUT HERE}

We first compared Language A and B to each other via a mixed effects model with random intercepts for subjects, items, and test condition. There were no overall differences between Languages $\mathrm{A}$ and $\mathrm{B}, \beta=0.26, S E=0.26, z=1.17, p=0.24$, and were therefore combined in further analyses.

Participants showed correct responses that were significantly higher than chance for the Old:Scrambled items, mean $=0.65, C I \pm 0.085, \beta=0.60, S E=0.22, z=2.79, p=0.00525$, and New:Scrambled(Easy) items, mean $=0.65, C I \pm 0.085, \beta=0.60, S E=0.22, z=2.79, p=0.0052$, 
but did not select the correct response significantly more often than chance for the New:NonWordHybrid items, mean $0.57, C I \pm 0.087, \beta=0.29, S E=0.21, z=1.40, p=0.16$, or Old:New items, mean $0.53, C I \pm 0.089, \beta=0.13, S E=0.21, z=0.625, p=0.53$.

Pairwise comparisons with Old:New items showed no significant differences between any other type of test item, Old:Scrambled, $\beta=0.47, S E=0.30, z=1.60, p=0.11$, New:Scrambled, $\beta=0.47, S E=0.30, z=1.60, p=0.11$, or New:NonWordHybrid items, $\beta=$ $0.16, S E=0.29, z=0.56, p=0.58$.

\section{Discussion}

Like adults in Experiments 1-2, participants in Experiment 3 were able to successfully recognize familiar CVCVC items, and extend the CCV 'roots' to novel CVCVC templates. Like adults in Experiment 1, participants in Experiment 3 were not able to distinguish between novel items and nonword hybrid items at a rate significantly higher than chance. However, because the means are similar to those of Experiment 2, it is likely that this may be due to low power rather than a failure to learn (though because the mean was less than $60 \%$, it is clear that the learning was not robust). Like Experiment 1, learners were not able to distinguish between familiar and novel items. This could be because, like in Experiment 1, participants used similarity to known items in their grammaticality decisions, and as the old and new items are highly similar to each other. It could also be due to a more abstract learning strategy, where participants used abstract representations that would not distinguish between old and new items.

\section{General Discussion}

We have presented the results from three artificial language learning experiments on morpheme segmentation of non-adjacent, non-concatenative morphological patterns. Learners exposed to a discontinuous non-concatenative morphological pattern were able to parse some 
aspects of the consonant patterns from the vowels. However, participants in Experiments 1 and 3 did not show significant differences between New and Nonword Hybrid items (though the means were numerically above $50 \%$ chance), and responses to New:Scrambled(Hard) items was only marginally above chance in Experiment 1. This suggests that learning may make use of similarity in their judgments about grammaticality. Use of similarity could reflect general perceptual mechanisms for parsing the non-concatenative morphology, or could be a factor in how learners parse consonantal roots, as languages with non-concatenative morphology tend to avoid consonantal roots that are highly similar (Frisch et al., 2004).

Participants in Experiment 3 were able to learn some aspects of the CCV roots, even though the patterns were based in a mix of consonants and vowels, which goes against the general typology of non-concatenative morphology. One possible explanation for this result is that learners extracted the $\mathrm{CC}$ part of the $\mathrm{CCV}$ root, and were able to make decisions based on the first two consonants. However, if this were the case, one would expect better performance on the New:NonWordHybrid items, since the nonword hybrid items split apart the consonants in the $\mathrm{CC}$ root. Another possible explanation is that participants made use of the syllabic structure in their representation of the pattern. Because the syllabic structure and the roots are at odds for New:NonWordHybrid items, participants failed to select the items at a rate higher than chance.

\section{Learning Mechanisms}

The present research extends the findings of previous computational models of nonhuman learners in important ways. Adult and child learners were able to parse CCC consonantal roots without any semantic information. Fullwood and O’Donnell (2013) used a computational model based on Bayesian inferences to simulate non-concatenative morpheme segmentation in Arabic. In their model, the learner was given access to templatic morphological representations 
that separated the roots from the 'residue'. The learner was then able to use probabilistic input to determine the roots and how the 'residue' fit into various templates. One question in applying the use of probability to a human learner is how the learner is able to know when it is statistically worthwhile to use templatic morphology. It is possible that distributional cues may inform the learner of the type of morphological system present in the input. For example the existence of high consistency in consonantal patterns among a large set of word forms may trigger a templatic structure. While learners in the present study were English speakers, who do not use templatic structure, it is still possible for learners in an artificial grammar to spontaneously form templates that conform to the input (Guest et al., 2000), suggesting that English speakers are either equipped with the mechanisms of templatic morphology, or can spontaneously form the necessary templatic structures, despite the fact that English is primarily a concatenative language (Fullwood, 2018).

The present paper may also shed light on the learning biases for non-adjacent dependencies. Learners were able to parse some aspects of the roots when the variation of the residues was especially high, supporting previous results suggesting that non-adjacent dependencies are best learned when the elements in between the adjacent elements are highly variable (Gomez, 2002). This further replicates this effect to non-concatenative morphology, and discontinuous elements at the word level. While we did not directly compare learnability for languages with high and low variation, additional research has suggested that participants require more training when variability is low (Finley \& Newport, 2020).

While high variability of irrelevant elements can help learners find non-adjacent dependencies (Gomez, 2002), high variation may also help learners in a variety of contexts. In learning concatenative morphology from distributional information, learners must form 
relationships between parts of words. If there is a high level of variance surrounded by a smaller amount consistency, then learners may find the regularities in place. For example, Finley and Newport (2010) showed that learners can extract affix information from exposure to 48 words made from 24 stems with 4 suffixes. While learners were able to discover both stems and affixes, the learnability of the affixes appeared to be more robust than learning of the stems, possibly because of the higher frequency of affixes compared to stems. In addition, learners are better able to generalize high frequency affixes to novel stems (Finley, 2015a). A question for future research is to understand how frequency and variation interact with linguistic and cognitive biases to help learners find the grammatical patterns that occur in the languages they learn.

One of the major contributions of the present work is that it demonstrates the ability of learners to parse discontinuous morphological elements in the form of non-concatenative morphology, without any semantic information. This suggests that learners may use statistical information to generate hypotheses about the regularities of the language, at the earliest stages of learning, before any knowledge of sentence structure, word meaning or usage may play a role. This information could be useful to help learners 'bootstrap' their knowledge of forms into systems of form, meaning and use. However, because the learning was not robust, it may suggest that learning non-adjacent dependencies may require additional information, including semantic cues or other types attentional or distributional cues to learning.

The present study explored the nature of distributional information required for learning to parse non-adjacent dependencies in words with a non-concatenative system based on consonantal roots and vowel patterns. In Experiment 3, we explored whether the roots needed to be consonantal, and exposed participants to CCV roots. Participants were able to learn some aspects of the language. These results are similar to Fullwood (2018), who trained English- 
speaking adults in an artificial grammar learning task in which the language was either concatenative, non-concatenative with consonantal roots, and non-concatenative with mixed consonant-vowel roots. In addition to a bias towards concatenative morphology, Fullwood (2018) found that participants were better at learning the pattern when the roots consisted of only consonants. While it is possible that this bias could be due to the fact that English morphology is primarily concatenative, Drake (2018) found a bias towards concatenative morphology even for speakers of languages with robust non-concatenative morphology, Arabic and Maltese (though Arabic speakers did perform better than English speakers on the non-concatenative language). This finding also held when the task was a nonce word production task (Drake, 2018, 2019). This suggests that there is a bias towards non-concatenative morphology, as well as a bias for non-concatenative morphology to have a clear separation of consonants and vowels.

\section{Limitations}

While the present study has important implications for understanding how we learn root and pattern morphology, there are some limitations to the current study. First, all of the templates that were used in the present study were always of the form CVCVC, while in natural languages, there are many different templates (e.g., CVCCV). It is possible that the variability in the types of templates might also serve as a cue for learners. When Finley and Newport (2020) added additional templates, learners performed similarly as in the present study, suggesting that additional templates do not detract from learning, but may not make the language significantly easier to learn.

Second, the number of vowel residues was unevenly distributed, with four frequent vowel residues and several infrequent residues, but participants were only tested on forms with the frequent vowel residues. It is possible that participants had separate representations for the 
frequent and the infrequent vowel residues, which may have influenced how participants interpreted the novel and ungrammatical items. In addition, the vowel patterns used in the present study were not matched across Language A and Language B. However, there were no overall differences between Language A and B, suggesting that these differences did not significantly affect the results.

Third, some test items were significantly above chance, and others were not, making interpreting what was learned somewhat difficult. For example, in Experiments 1 and 3, responses to New:NonWordHybrid items were not significantly above chance, but they were for both adults and children in Experiment 2. Because the means were similar across all three experiments for these items, it is unlikely that participants in Experiment 2 learned the language better than participants in Experiments 1 and 3. However, the comparison between children and adults for New:OldScrambled(Easy) items in Experiment 2 was statistically significant, suggesting that there was a difference in learning in that experiment.

\section{Future Research}

There are several areas that the present study opens for future research. First, there is a need to better understand how children and adults learn non-adjacent patterns differently. In the present study, children did not outperform adults in their ability to recognize novel items. This could be because the task demands did not adequately assess their learning. Since two alternative forced choice tasks require the participant to keep in memory both items before making a response, small differences between items could easily be forgotten, potentially masking the children's responses. Future research could employ different techniques to better assess learnability in both children and adults.

Second, participants in Experiment 1 only showed a marginally significant effect for 
New:Scrambled(Hard) items, suggesting a relatively weak ability to successfully differentiate new items from familiar scrambled items that were similar to the training items. This was the same result obtained in Finley and Newport (2020). It is not clear whether this is due to an edge effect, where participants memorized the edges of the words (particularly the first consonant), or if it was due to a perceptual difference, since the scrambled options in the New:OldScrambled(Hard) items changed were perceptually very close to items in the training set, but also left the initial consonant intact. Future research could address specific questions related to edge effects and perceptual similarity, teasing apart how these two factors play a role in learning non-concatenative morphology. Future studies could extend the work on non-adjacent dependencies at the sentence level to morpheme segmentation. It is possible that similar constraints may govern how learners segment non-adjacent dependencies in morphology.

\section{Conclusions}

The present study explored the learnability of non-concatenative, root and pattern morphology in adults and children. Three experiments used an artificial language with CVCVC templates that contained 12 regular patterns (CCC in Experiments 1-2, and CCV in Experiment 3), and several highly variable residues to fill the templates. It was shown that learners can extract regularities from the training set, without reference to meaning, even when the roots contained a mix of consonants and vowels. However, this learning may be constrained, demonstrating a possible bias against non-adjacent dependencies in morphology. 


\section{References}

Ambridge, B. (2010). Children's judgments of regular and irregular novel past-tense forms: New data on the english past-tense debate. Developmental Psychology, 46(6), 1497-1504. https://doi.org/10.1037/a0020668

Barr, D. J., Levy, R., Scheepers, C., \& Tily, H. J. (2013). Random effects structure for confirmatory hypothesis testing: Keep it maximal. Journal of Memory and Language, 68(3), 255-278. https://doi.org/10.1016/j.jml.2012.11.001

Bates, D., Mächler, M., Bolker, B., \& Walker, S. (2015). Fitting linear mixed-effects models using \{lme4\}. Journal of Statistical Software, 67, 1-48.

https://doi.org/10.18637/jss.v067.i01

Bonatti, L. L., Peña, M., Nespor, M., \& Mehler, J. (2005). Linguistic constraints on statistical computations: the role of consonants and vowels in continuous speech processing. Psychological Science : A Journal of the American Psychological Society / APS, 16(6), 451-459. https://doi.org/10.1111/j.0956-7976.2005.01556.x

Bonatti, L. L., Peña, M., Nespor, M., \& Mehler, J. (2007). On consonants, vowels, chickens, and eggs. Psychological Science, 18(10), 924-925. https://doi.org/10.1111/j.14679280.2007.02002.x

Burness, P., \& McMullin, K. (2019). Efficient learning of output tier-based strictly 2-local functions. In Proceedings of the 16th Meeting on the Mathematics of Language (pp. 78-90). Association for Computational Linguistics.

Chandlee, J. (2014). Strictly local phonological processes. PhD Dissertation, University of Delaware.

Clements, G. N. (1985). The geometry of phonological features. Phonology, 2(1985), 225-252. 
https://doi.org/10.1017/S0952675700000440

Drake, S. N. (2018). L1 Biases in Learning Root-and-Pattern Morphology. University of Arizona.

Drake, S. N. (2019). What Can a Wug Test Tell Us About Abstract Morpheme Storage? 11th International Conference on the Mental Lexicon, 11(1), e112.

Finley, S. (2011). The privileged status of locality in consonant harmony. Journal of Memory and Language, 65(1), 74-83.

Finley, S. (2012). Testing the Limits of Long-Distance Learning: Learning Beyond a ThreeSegment Window. Cognitive Science, 36(4), 740-756.

Finley, S. (2015a). Frequency effects in morpheme segmentation. In Proceedings of the 37th Annual Conference of the Cognitive Science Society (pp. 704-709). Cognitive Science Society.

Finley, S. (2015b). Learning nonadjacent dependencies in phonology: Transparent vowels in vowel harmony. Language, 91(1), 48-72. https://doi.org/10.1353/lan.2015.0010

Finley, S., \& Badecker, W. (2009). Artificial language learning and feature-based generalization. Journal of Memory and Language, 61(3), 423-437.

Finley, S., \& Newport, E. L. (2010). Morpheme segmentation from distributional information. In J. Chandleee, K. Franich, K. Iserman, \& K. L. (Eds.), BUCLD 34 Proceedings Supplement, online. BUCLD.

Finley, S., \& Newport, E. L. (2011). Morpheme segmentation in school-aged children. In A. Fine (Ed.), Rochester working papers in the language sciences. MIT Press.

Finley, S., \& Newport, E. N. (2020). Segmentation of Root and Pattern Morphology.

Frisch, S., Pierrehumbert, J. B., \& Broe, M. B. (2004). Similarity avoidance and the OCP. 
Natural Language \& Linguistic Theory, 22(1), 179-228.

Frost, R. L. A., \& Monaghan, P. (2016). Simultaneous segmentation and generalisation of nonadjacent dependencies from continuous speech. Cognition, 146, 70-74. https://doi.org/https://doi.org/10.1016/j.cognition.2015.11.010

Fullwood, M. A. (2018). Biases in segmenting non-concatenative morphology. PhD Dissertation, MIT.

Fullwood, M. A., \& O’Donnell, T. J. (2013). Learning non-concatenative morphology. In Proceedings of the Workshop on Cognitive Modeling and Computational Linguistics (pp. 21-27). Association for Computational Linguistics.

Goldsmith, J. A. (1976). Autosegmental phonology. MIT.

Goldsmith, J. A. (1975). Tone melodies and the autosegment. Proceedings of the 6th Conference on African Linguistics, 135-147.

Gomez, R. L. (2002). Variability and detection of invariant structure. Psychological Science, $13(5), 431-436$.

Gomez, R. L., \& Maye, J. (2005). The developmental trajectory of nonadjacent dependency learning. Infancy, 7(2), 183-206.

Guest, D. J., Dell, G. S., \& Cole, J. S. (2000). Violable constraints in language production: Testing the transitivity assumption of Optimality Theory. Journal of Memory and Language, 42(2), 272-299.

Hansson, G. Ó. (2001). Theoretical and typological issues in consonant harmony. PhD Dissertation University of California, Berkeley.

Hansson, G. Ó. (2010). Consonant harmony: Long-distance interactions in phonology. University of California Press. 
Heinz, J. (2010). Learning long-distance phonotactics. Linguistic Inquiry, 41(4), 623-661.

Hudson Kam, C. L., \& Newport, E. L. (2005). Regularizing unpredictable variation: The roles of adult and child learner in language formation and change. Language Learning and Development, 1, 151-195.

Hudson Kam, C. L., \& Newport, E. N. (2009). Getting it right by get- ting it wrong: When learners change languages. Cognitive Psychology, 59, 30-66.

Martin, A., \& White, J. C. (2020). Vowel harmony and disharmony are not equivalent in learning. Linguistic Inquiry. https://doi.org/10.1162/ling_a_00375

McCarthy, J. J. (1981). A prosodic theory of nonconcatenative morphology. Linguistic Inquiry, $12(3), 373-418$.

McCarthy, J. J., \& Prince, A. (1990). Prosodic morphology and templatic morphology. In M. Eid \& J. McCarthy (Eds.), Perspectives on Arabic Linguistics: Papers from the Second Symposium (pp. 1-54). Benjamins.

McMullin, K. (2016). Tier-based locality in long-distance phonotacitcs: Leanability and typology. PhD Dissertation, University of British Columbia.

McMullin, K., \& Hansson, G. Ó. (2014). Locality in long-distance phonotactics: evidence for modular learning. In Proceedings of NELS 44.

McMullin, K., \& Hansson, G. Ó. (2019). Inductive learning of locality relations in segmental phonology. Laboratory Phonology, 10(1), 14. https://doi.org/10.5334/labphon.150

Mehler, J., Pena, M., Nespor, M., \& Bonat. (2006). The "soul” of language does not use statistics: Reflection on vowels and consonants. Cortex, 42.

Misyak, J. B., \& Christiansen, M. H. (2007). Extending statistical learning farther and further: Long-distance dependencies, and individual differences in statistical language learning. In 
D. S. McNamara \& J. G. Trafton (Eds.), Proceedings of the 29th Annual Conference of the Cognitive Science Society (pp. 1307-1312). Cognitive Science Society.

Misyak, J. B., Christiansen, M. H., \& Tomblin, B. (2009). Statistical learning of nonadjacent dependencies predicts on-line processing of long-distance dependencies in natural language. In N. Taatgen \& H. van Rijn (Eds.), Proceedings of the 31st Annual Conference of the Cognitive Science Society (pp. 177-182). Cognitive Science Society.

Newport, E. L. (1990). Maturational constraints on language learning. Cognitive Science, 14, 1128.

Newport, E. L., \& Aslin, R. N. (2004). Learning at a distance I. Statistical learning of nonadjacent dependencies. Cognitive Psychology, 48, 127-162.

Prasada, S., \& Pinker, S. (1993). Generalisation of regular and irregular morphological patterns. Language and Cognitive Processes, 8(1), 1-56. https://doi.org/10.1080/01690969308406948

R Development Core Team, R. (2018). R: A language and environment for statistical computing. In R. D. C. Team (Ed.), R Foundation for Statistical Computing (Vol. 1, Issue 2.11.1, p. 409). R Foundation for Statistical Computing. https://doi.org/10.1007/978-3-540-74686-7

RStudio Team. (2020). RStudio: Integrated Development for R. 2020. http://www.rstudio.com/

Rumelhart, D. E., \& McClelland, J. (1986). On learning the past tenses of English verbs: Implicit rules or parallel distributed processing? In J. McClelland, D. E. Rumelhart, \& PDPResearchGroup (Eds.), Parallel distributed processing: Explorations in the microstructure of cognition, Volume II. (pp. 216-271). The MIT Press.

Samara, A., \& Caravolas, M. (2014). Statistical learning of novel graphotactic constraints in children and adults. Journal of Experimental Child Psychology, 121, 137-155. 
https://doi.org/https://doi.org/10.1016/j.jecp.2013.11.009

Thiessen, E. D. (2010). Effects of visual Information on adults' and infants' auditory statistical learning. Cognitive Science, 34(6), 1093-1106. https://doi.org/10.1111/j.15516709.2010.01118.x

Toro, J. M., Nespor, M., Mehler, J., \& Bonatti, L. L. (2008). Finding words and rules in a speech stream: Functional differences between vowels and consonants. Psychological Science, 19, $137-144$.

Wilson, B., Spierings, M., Ravignani, A., Mueller, J. L., Mintz, T. H., Wijnen, F., van der Kant, A., Smith, K., \& Rey, A. (2020). Non-adjacent Dependency Learning in Humans and Other Animals. Topics in Cognitive Science, 12(3), 843-858. https://doi.org/10.1111/tops.12381 
Table 1

Example Training Items (Experiments 1-2)

\begin{tabular}{|c|c|c|}
\hline Language & Frequent Vowel Patterns & Infrequent Vowel Patterns \\
\hline \multirow[t]{4}{*}{ A } & fikas, fikis & fækes, fekes \\
\hline & bidag, bidig & bedæg, bodkg \\
\hline & kitas, kutis & ketes, kitæs \\
\hline & duzig, dazug & dæzIg, d^zIg \\
\hline \multirow[t]{4}{*}{ B } & pakit, pukat & $\mathrm{p} \wedge$ kIt, pekot \\
\hline & kifus, kufus & kefos, kefis \\
\hline & supat, siput & sopet, sæpet \\
\hline & buguv, bagiv & $\mathrm{b} \wedge \mathrm{gIV}, \mathrm{bægæv}$ \\
\hline
\end{tabular}


Table 2

Example Test Items (Experiments 1-2)

\begin{tabular}{|c|c|c|}
\hline & Language A & Language B \\
\hline $\begin{array}{l}\text { Old:Scrambled (Exp 1) } \\
\left(\mathrm{C}_{1} \mathrm{~V}_{\mathrm{A}} \mathrm{C}_{2} \mathrm{~V}_{\mathbf{B}} \mathrm{C}_{3} \text { vs. } \mathrm{C}_{1} \mathrm{~V}_{\mathrm{A}} \mathrm{C}_{3} \mathrm{~V}_{\mathbf{B}} \mathrm{C}_{2}\right)\end{array}$ & $\begin{array}{l}\text { kaput *katup } \\
\text { tipis *tisip }\end{array}$ & $\begin{array}{l}\text { kifus } * \text { kisuf } \\
\text { tafip } * \text { tifap }\end{array}$ \\
\hline $\begin{array}{l}\text { Old:Scrambled (Exp 2) } \\
\left(\mathrm{C}_{1} \mathrm{~V}_{\mathrm{A}} \mathrm{C}_{2} \mathrm{~V}_{\mathbf{B}} \mathrm{C}_{3} \text { vs. } \mathrm{C}_{1} \mathrm{~V}_{\mathrm{A}} \mathrm{C}_{3} \mathrm{~V}_{\mathbf{B}} \mathrm{C}_{2}\right)\end{array}$ & $\begin{array}{l}\text { kaput *katup } \\
\text { tipis *tisip }\end{array}$ & $\begin{array}{l}\text { kifus } * \text { kisuf } \\
\text { tafip } * \text { tifap }\end{array}$ \\
\hline $\begin{array}{l}\text { New:Scrambled(Hard) } \\
\left(\mathrm{C}_{1} \mathrm{~V}_{\mathrm{X}} \mathrm{C}_{2} \mathrm{~V}_{\mathrm{Y}} \mathrm{C}_{3} \text { vs. } \mathrm{C}_{1} \mathrm{~V}_{\mathrm{A}} \mathrm{C}_{3} \mathrm{~V}_{\mathbf{B}} \mathrm{C}_{2}\right)\end{array}$ & $\begin{array}{l}\text { givaz } * \text { giziv } \\
\text { tupis } * \text { tisap }\end{array}$ & $\begin{array}{l}\text { duvaz } * \text { dizuv } \\
\text { fukat } * \text { futuk }\end{array}$ \\
\hline $\begin{array}{l}\text { New:NonWord Hybrid } \\
\left(\mathrm{C}_{1} \mathrm{~V}_{\mathrm{X}} \mathrm{C}_{2} \mathrm{~V}_{\mathrm{Y}} \mathrm{C}_{3} \text { Vs. }\left(\mathrm{C}_{1} \mathrm{~V}_{\mathrm{A}}\right)\left(\mathrm{C}_{2} \mathrm{~V}_{\mathrm{B}} \mathrm{C}_{3}\right)\right)\end{array}$ & $\begin{array}{l}\text { badug *bugav } \\
\text { sukat *sukus }\end{array}$ & $\begin{array}{l}\text { biguv *bafis } \\
\text { sufuk } * \text { sivad }\end{array}$ \\
\hline $\begin{array}{l}\text { New:Scrambled(Easy) } \\
\left(\mathrm{C}_{1} \mathrm{~V}_{\mathrm{X}} \mathrm{C}_{2} \mathrm{~V}_{\mathrm{Y}} \mathrm{C}_{3} \text { vs. } \mathrm{C}_{3} \mathrm{~V}_{\mathrm{A}} \mathrm{C}_{1} \mathrm{~V}_{\mathbf{B}} \mathrm{C}_{2}\right)\end{array}$ & $\begin{array}{l}\text { fukis } *_{\text {sifik }} \\
\text { tapus } *_{\text {sitip }}\end{array}$ & $\begin{array}{l}\text { dazig * gudaz } \\
\text { vibag *buvig }\end{array}$ \\
\hline $\begin{array}{l}\text { Old:New } \\
\left(\mathrm{C}_{1} \mathrm{~V}_{\mathrm{A}} \mathrm{C}_{2} \mathrm{~V}_{\mathbf{B}} \mathrm{C}_{3} \text { vs. } \mathrm{C}_{1} \mathrm{~V}_{\mathrm{X}} \mathrm{C}_{2} \mathrm{~V}_{\mathrm{Y}} \mathrm{C}_{3}\right)\end{array}$ & $\begin{array}{l}\text { sikat } * \text { sakut } \\
\text { vazub } * \text { vuzib }\end{array}$ & $\begin{array}{l}\text { kufus *kufas } \\
\text { zugab *zigub }\end{array}$ \\
\hline
\end{tabular}




\section{Table 3}

Example Training Items (Experiment 3)

\begin{tabular}{lll} 
Language & Frequent VC & Infrequent VC \\
\hline A & sofik, sifit & safip, sæfit \\
& gemum, gumub & gimuz, gemuk \\
& tovek, tevem & tIveg, tuves \\
& zegom, zogob & zugov, zægot \\
povap, pivav & pIvaf, puvan \\
B & tosep, tisev & tesep, tisev \\
& donup, denud & dinup, denuv \\
& mobep, mubet & mebet, mæbed
\end{tabular}


Table 4

Example Test Items (Experiment 3)

\begin{tabular}{l|ll} 
& Language $A$ & Language $B$ \\
\hline Old:Scrambled & sofik vs. fisok & povap vs. vapop \\
$\mathrm{C}_{1} \mathrm{~V}_{\mathrm{A}} \mathrm{C}_{2} \mathrm{~V}_{3} \mathrm{C}_{\mathrm{B}}$ vs. $\mathrm{C}_{2} \mathrm{~V}_{3} \mathrm{C}_{1} \mathrm{~V}_{\mathrm{A}} \mathrm{C}_{\mathrm{B}}$ & gumub vs. mugub & tisev vs. setiv \\
New:NonWord Hybrid & kenum vs. somub & vipuv vs. bemuv \\
$\mathrm{C}_{1} \mathrm{~V}_{\mathrm{X}} \mathrm{C}_{2} \mathrm{~V}_{3} \mathrm{C}_{\mathrm{Y}}$ vs. $\left(\mathrm{C}_{1} \mathrm{~V}_{\mathrm{A}} \mathrm{C}_{2}\right)\left(\mathrm{V}_{3} \mathrm{C}_{\mathrm{B}}\right)$ & dokik vs. bisuk & suket vs. degip \\
New:Scrambled(Easy) & sefim vs. fisit & puvat vs. vapiv \\
$\mathrm{C}_{1} \mathrm{~V}_{\mathrm{X}} \mathrm{C}_{2} \mathrm{~V}_{3} \mathrm{C}_{\mathrm{Y}}$ vs. $\mathrm{C}_{2} \mathrm{~V}_{3} \mathrm{C}_{1} \mathrm{~V}_{\mathrm{A}} \mathrm{C}_{\mathrm{B}}$ & gimut vs. mugem & tesed vs. setop \\
Old:New & kinut vs. konuk & negid vs. nogip \\
$\mathrm{C}_{1} \mathrm{~V}_{\mathrm{A}} \mathrm{C}_{2} \mathrm{~V}_{3} \mathrm{C}_{\mathrm{B}}$ vs. $\mathrm{C}_{1} \mathrm{~V}_{\mathrm{X}} \mathrm{C}_{2} \mathrm{~V}_{3} \mathrm{C}_{\mathrm{Y}}$ & mopok vs. mepom & fumut vs. fomup \\
& &
\end{tabular}


Figure 1

Means and Standard Errors of the Mean, Experiment 1

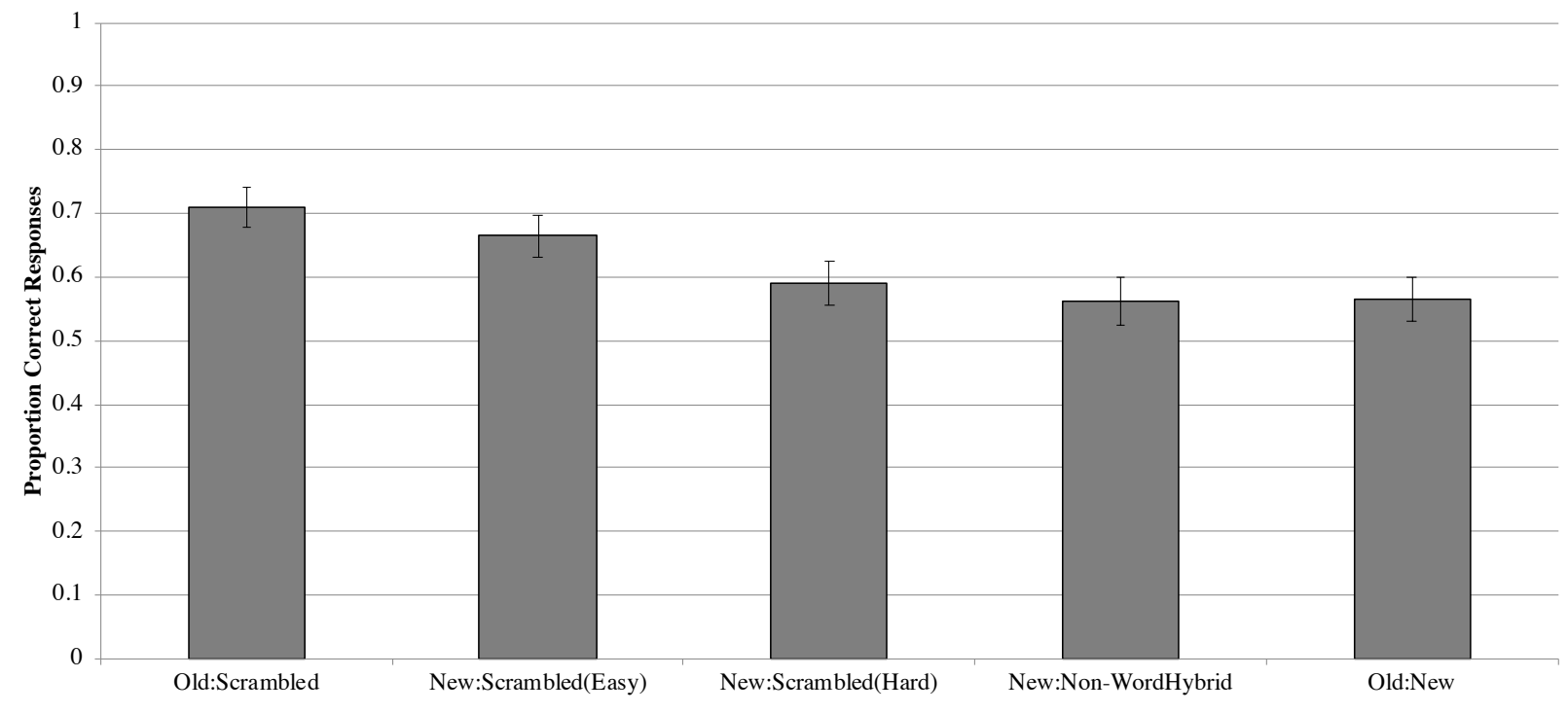


Non-Concatenative Morpheme Segmentation 41

Figure 2

Example of a 'Silly Person'

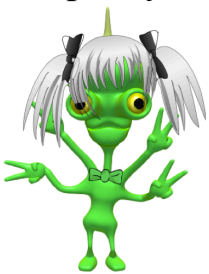


Figure 3

Means and Standard Errors of the Mean, Experiment 2

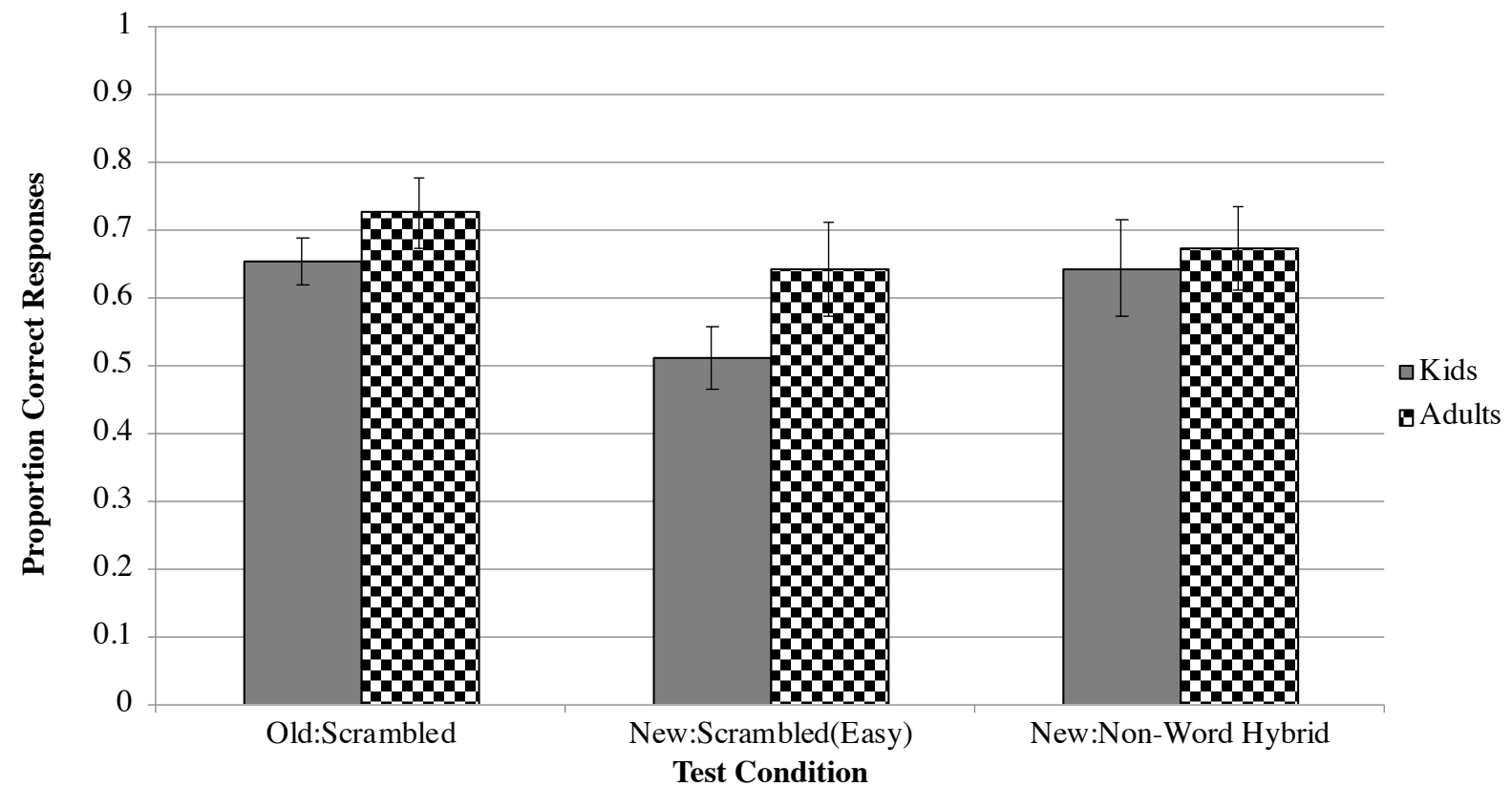


Figure 4

Means and Standard Errors of the Mean, Experiment 3

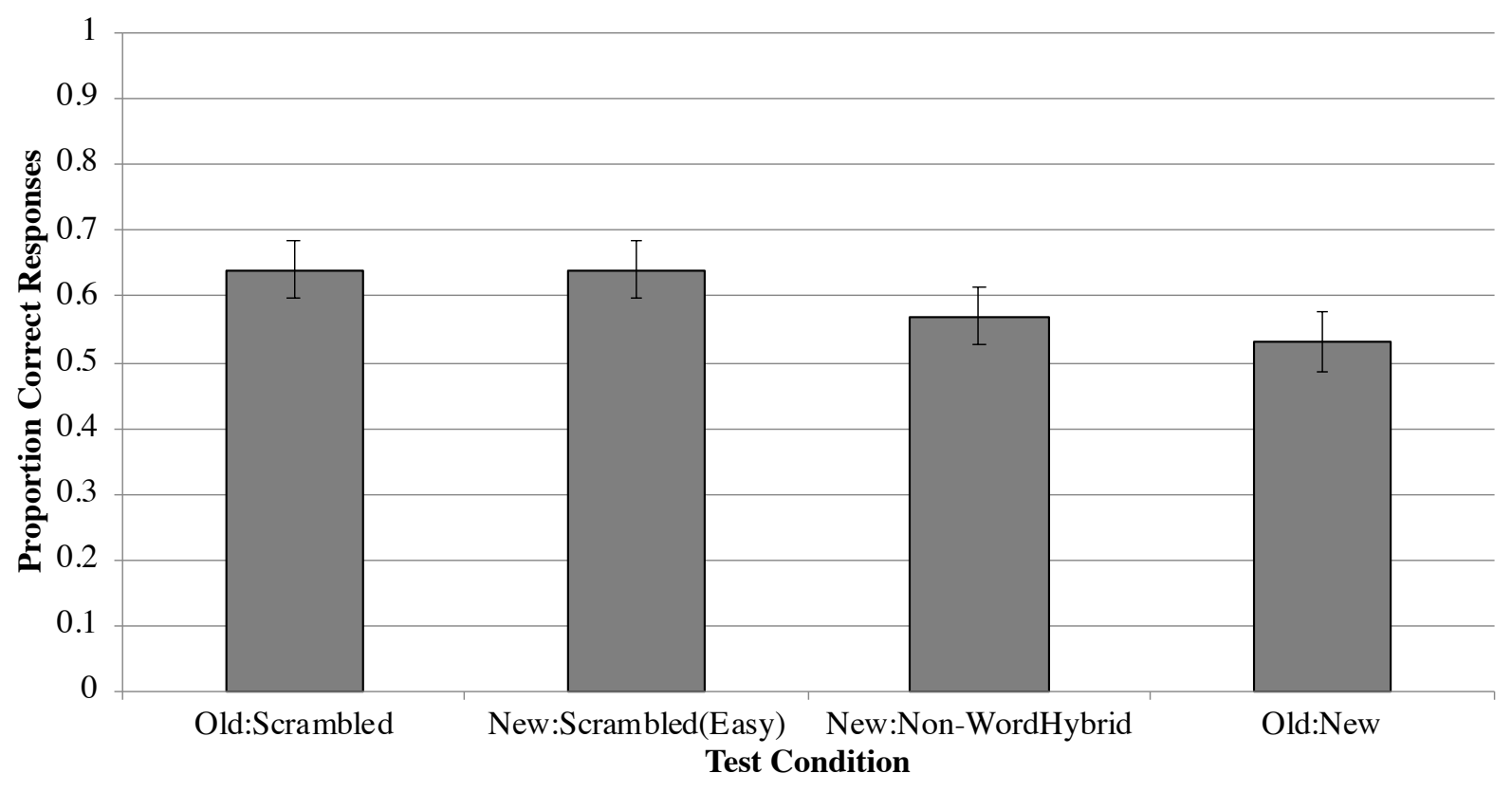


Appendix A: Stimuli List, Experiments 1-2

Training Items:

\begin{tabular}{|c|c|}
\hline Language A & Language $B$ \\
\hline bAEdog & b_gIv \\
\hline bed $^{\wedge} \mathrm{g}$ & bAEg_v \\
\hline bedAEg & bagiv \\
\hline bidag & bEgAEv \\
\hline bidig & begEv \\
\hline bodEg & buguv \\
\hline$d^{\wedge}$ zeg & d_vez \\
\hline $\mathrm{d}^{\wedge} \mathrm{zIg}$ & $\mathrm{d} \overline{\mathrm{A}} \mathrm{EvEz}$ \\
\hline dAEzEg & dEvez \\
\hline dAEzIg & dezAEg \\
\hline dazug & dEzog \\
\hline $\mathrm{dIg}^{\wedge} \mathrm{V}$ & dIV_z \\
\hline dIgAEv & divuz \\
\hline digav & dIzIg \\
\hline digiv & dizug \\
\hline $\operatorname{dog}^{\wedge} v$ & doz_g \\
\hline dogev & duvuz \\
\hline duzig & duzag \\
\hline $\mathrm{f}^{\wedge} \mathrm{kos}$ & fAEket \\
\hline fAEkEs & fakit \\
\hline $\mathrm{fEk}^{\wedge} \mathrm{s}$ & fEkIt \\
\hline fEkes & flkot \\
\hline fikas & fok_t \\
\hline fikis & fukut \\
\hline gavuz & gAEvId \\
\hline $\mathrm{gEv}^{\wedge} \mathrm{z}$ & gEvAEd \\
\hline gEvez & gevod \\
\hline gIvEz & givud \\
\hline gIvez-2 & gov_d \\
\hline giviz & guvud \\
\hline kaput & kefIs \\
\hline kepEt & kEfos \\
\hline kepIt & kIf_s \\
\hline kEtAEs & kifūs \\
\hline ketEs & kofAEs \\
\hline kIpAEt & kufus \\
\hline kItAEs & p_kIt \\
\hline kitas & pakit \\
\hline kopAEt & pEkot \\
\hline kotEs & pIket \\
\hline kupit & pokAEt \\
\hline kutis & pukat \\
\hline
\end{tabular}




$\begin{array}{ll}\text { sEk^t } & \text { s_fAEk } \\ \text { sikat } & \text { s_pIt } \\ \text { sIkEt } & \text { sAEpet } \\ \text { sokAEt } & \text { sAfIk_- } \\ \text { sokEt } & \text { sEf_k } \\ \text { sukit } & \text { sepot } \\ t^{\wedge} \text { fIp } & \text { sIfEk } \\ t^{\wedge} \text { fop } & \text { sifuk } \\ \text { t`pos }^{\wedge} & \text { siput } \\ \text { tAEpes } & \text { sopEt } \\ \text { tafup } & \text { sufak } \\ \text { tef^p } & \text { supat } \\ \text { tepIs } & \text { tAEfep } \\ \text { tipas } & \text { tafip } \\ \text { tipis } & \text { tEfop } \\ \text { tIpos } & \text { tIfAEp } \\ \text { tofEp } & \text { tof_p } \\ \text { tufip } & \text { tufup } \\ \text { vAEzeb } & \text { v_dAEz } \\ \text { vazub } & \text { vadiz } \\ \text { vEzAEb } & \text { vAEdoz } \\ \text { vEzob } & \text { vEdIz } \\ \text { vizib } & \text { vodez } \\ \text { vIzob } & \text { vudaz } \\ z^{\wedge} \text { bId } & \text { z_gob } \\ \text { zabud } & \text { zAEgEb } \\ \text { zAEb^d } & \text { zagib } \\ \text { zAEbed } & \text { zIgeb } \\ \text { zEbId } & \text { zogIb } \\ \text { zubid } & \text { zugab } \\ & \\ & \end{array}$

$\underline{\text { Test Items: }}$

Language A:

$\begin{array}{lll}\text { Item Type } & \text { Correct Response } & \text { Incorrect Response } \\ \text { New:NonWord Hybrid } & \text { badug } & \text { bugav } \\ & \text { dugiv } & \text { dadag } \\ & \text { dizag } & \text { duzib } \\ & \text { fukis } & \text { fikat } \\ & \text { kipat } & \text { kafup } \\ & \text { sakut } & \text { sukus } \\ & \text { tifip } & \text { tukip } \\ & \text { vuzib } & \text { vuzig } \\ \text { New:Scrambled(Hard) } & \text { badug } & \text { bigad } \\ & \text { daguv } & \text { divig }\end{array}$




$\begin{array}{cll} & \text { dizig } & \text { daguz } \\ & \text { givaz } & \text { giziv } \\ & \text { kipat } & \text { kutip } \\ & \text { tupis } & \text { tisap } \\ & \text { zibad } & \text { zudib } \\ \text { zibid } & \text { zadub } \\ \text { New:Scrambled(Easy) } & \text { dizag } & \text { gudiz } \\ & \text { fakus } & \text { sifak } \\ & \text { dizig } & \text { gaduz } \\ & \text { fukis } & \text { sifik } \\ & \text { sikit } & \text { tisak } \\ & \text { kipit } & \text { takup } \\ & \text { tapus } & \text { sitip } \\ & & \\ & & \\ \text { Old:Scrambled } & \text { bidig } & \text { bigid } \\ & \text { fikas } & \text { fisak } \\ & \text { gavuz } & \text { gazuv } \\ & \text { kaput } & \text { katup } \\ & \text { kitas } & \text { kisat } \\ & \text { sukit } & \text { sutik } \\ & \text { tipis } & \text { tisip } \\ \text { tufip } & \text { tupif }\end{array}$

Language B:

$\begin{array}{lll}\text { Item Type } & \text { Correct Response } & \text { Incorrect Response } \\ \text { New:NonWord Hybrid } & \text { biguv } & \text { bafis } \\ & \text { dazig } & \text { dizag } \\ & \text { fukat } & \text { fafik } \\ & \text { pikut } & \text { pagab } \\ & \text { sapit } & \text { sikut } \\ & \text { sufuk } & \text { sivad } \\ & \text { tufap } & \text { tasip } \\ & \text { vuduz } & \text { vugib } \\ \text { New:Scrambled(Easy) } & \text { biguv } & \text { buvug } \\ & \text { dagiz } & \text { duzig } \\ & \text { duvaz } & \text { dizuv } \\ & \text { fikut } & \text { fatik } \\ & \text { fukat } & \text { futuk } \\ & \text { guvad } & \text { giduv } \\ & \text { suput } & \text { sutap } \\ & \text { tifup } & \text { tupuf } \\ \text { New:Scrambled(Hard) } & \text { zugub } & \text { bazig } \\ & \text { bugav } & \text { vabig } \\ & \text { dazig } & \text { gudaz }\end{array}$




$\begin{array}{lll} & \text { gavid } & \text { duguv } \\ \text { kafis } & \text { sikuf } \\ \text { tufap } & \text { putuf } \\ \text { sapit } & \text { tusap } \\ \text { daviz } & \text { ziduv } \\ \text { dizug } & \text { duzug } \\ \text { fakit } & \text { fikut } \\ \text { kufus } & \text { kufas } \\ \text { pakit } & \text { pikut } \\ \text { sufak } & \text { safik } \\ & \text { sifuk } & \text { sufuk } \\ \text { tufup } & \text { tifup } \\ \text { zugab } & \text { zigub } \\ \text { duzag } & \text { dugaz } \\ \text { duvuz } & \text { duzuv } \\ \text { guvud } & \text { guduv } \\ \text { kifus } & \text { kisuf } \\ \text { siput } & \text { situp } \\ \text { tafip } & \text { tapif } \\ \text { zagib } & \text { zabig } \\ \text { zugab } & \text { zubag }\end{array}$


Appendix B: Stimuli List, Experiment 3

Training Items: Language A

$\begin{array}{llllllll}\text { sofik } & \text { sefim } & \text { sifit } & \text { sufib } & \text { safip } & \text { sAEfit } & \text { sofin } & \text { sIfiv } \\ \text { gomuk } & \text { gemum } & \text { gimut } & \text { gumub } & \text { gImuz } & \text { gUmup } & \text { gAEmub } & \text { gEmuk } \\ \text { botak } & \text { betam } & \text { bitat } & \text { butab } & \text { bUtag } & \text { botav } & \text { bItaz } & \text { bEtap } \\ \text { nosuk } & \text { nesum } & \text { nisut } & \text { nusub } & \text { nAEsuv } & \text { nUsuf } & \text { nisun } & \text { nusud } \\ \text { fozik } & \text { fezim } & \text { fizit } & \text { fuzib } & \text { fEzin } & \text { fAEzig } & \text { fUziv } & \text { fIzip } \\ \text { podek } & \text { pedem } & \text { pidet } & \text { pudeb } & \text { pEdes } & \text { pudeg } & \text { pAEdep } & \text { pIden } \\ \text { vobak } & \text { vebam } & \text { vibat } & \text { vubab } & \text { vAEbap } & \text { vUbaz } & \text { vEbag } & \text { viban } \\ \text { tovek } & \text { tevem } & \text { tivet } & \text { tuveb } & \text { tIveg } & \text { tuves } & \text { tEvep } & \text { tuven } \\ \text { konuk } & \text { kenum } & \text { kinut } & \text { kunub } & \text { kAEnus } & \text { kInup } & \text { kEnuf } & \text { kinug } \\ \text { dokik } & \text { dekim } & \text { dikit } & \text { dukib } & \text { dUkin } & \text { dAEkis } & \text { dukip } & \text { dEkiv } \\ \text { mopok } & \text { mepom } & \text { mipot } & \text { mupob } & \text { mEpof } & \text { mipon } & \text { mUpod } & \text { mAEpog } \\ \text { zogok } & \text { zegom } & \text { zigot } & \text { zugob } & \text { zugov } & \text { zIgop } & \text { zAEgot } & \text { zEgod }\end{array}$

Training Items: Language B

\begin{tabular}{llllllll}
\hline povap & pevad & pivav & puvat & pAEvad & pIvaf & puvan & pEvas \\
tosep & tesed & tisev & tuset & tUseg & tEsep & tIsev & teseb \\
kozip & kezid & kiziv & kuzit & kEzid & kAEzip & kuzif & kIziz \\
bofop & befod & bifov & bufot & bUfoz & befod & bAEfop & bIfog \\
donup & denud & dinuv & dunut & dAEnug & dInup & denuv & dUnun \\
godakp & gedad & gidav & gudat & gUdaf & gedap & gIdag & gEdak \\
mobep & mebed & mibev & mubet & mEbet & mAEbed & mIbep & mubez \\
nogip & negid & nigiv & nugit & nAEgis & nUgip & nEgif & nogid \\
fomup & femud & fimuv & fumut & fImun & fEmup & fAEmuz & fimud \\
zotop & zetod & zitov & zutot & zAEtod & zetop & zUtog & zEtos \\
sokep & seked & sikev & suket & sIked & sAEken & sekep & sEkev \\
vopup & vepud & vipuv & vuput & vIpuz & vEpug & vAEpud & vipun
\end{tabular}

Test Items: Language A

$\begin{array}{lll}\text { Item Type } & \text { Correct Response } & \text { Incorrect } \\ \text { New:NonWord Hybrid } & \text { kenum } & \text { somub } \\ & \text { dokik } & \text { Bisuk } \\ & \text { mepom } & \text { fedet } \\ & \text { zigot } & \text { vuvem } \\ & \text { sufib } & \text { kapok } \\ & \text { gomuk } & \text { digom } \\ & \text { nisut } & \text { gebab } \\ & \text { fuzib } & \text { netat } \\ & & \\ \text { New:Scrambled(Easy) } & \text { sefim } & \text { fisit } \\ & \text { gimut } & \text { mugok } \\ & \text { botak } & \text { tabub } \\ & \text { nusub } & \text { sunem }\end{array}$




$\begin{array}{lll} & \text { fozik } & \text { zifit } \\ \text { pedem } & \text { depok } \\ \text { vibat } & \text { bavem } \\ \text { tuveb } & \text { vetok } \\ \text { kinut } & \text { konuk } \\ \text { dekim } & \text { dukib } \\ \text { mopok } & \text { mepom } \\ \text { zugob } & \text { zigot } \\ & \text { gifit } & \text { sefim } \\ \text { gemum } & \text { gamut } \\ \text { nosuk } & \text { nusub } \\ \text { butab } & \text { botak } \\ \text { sofik } & \text { fisok } \\ \text { gumub } & \text { mugub } \\ & \text { bitat } & \text { tabit } \\ \text { nosuk } & \text { sunok } \\ \text { fezim } & \text { zifem } \\ \text { pidet } & \text { depit } \\ \text { vubab } & \text { bavub } \\ \text { tevem } & \text { vetem }\end{array}$

Test Items: Language B

Item Type

New:NonWord Hybrid

\section{Correct Response Incorrect Response}

vipuv

suket

zutot

mebed

godap

dinuv

kozip

befod

New:Scrambled(Easy)

$\begin{array}{ll}\text { puvab } & \text { vapiv } \\ \text { tesed } & \text { setop } \\ \text { vepud } & \text { puvut } \\ \text { fimuv } & \text { mufed } \\ \text { nigiv } & \text { gined } \\ \text { zotop } & \text { toziv } \\ \text { dunut } & \text { nudop } \\ \text { bofop } & \text { fobut }\end{array}$

bomuv

degip

kitot

tupud

sivat

goked

nudap

zekev

vapiv

setop

puvut

ined

gined

nudop

fobut 


$\begin{array}{lll}\text { Old:New } & \text { negid } & \text { nogip } \\ \text { mobep } & \text { mibev } \\ \text { fumut } & \text { fomup } \\ \text { kuzit } & \text { kiziv } \\ \text { gedad } & \text { gudat } \\ \text { sikev } & \text { seked } \\ \text { tosep } & \text { tuset } \\ \text { pivat } & \text { pevad } \\ \text { povap } & \text { vapop } \\ \text { tisev } & \text { setiv } \\ \text { keziv } & \text { zikev } \\ \text { donut } & \text { nudot } \\ & \text { gidav } & \text { dagiv } \\ \text { mubet } & \text { bemut } \\ & \text { zetod } & \text { tozed } \\ & \text { vupet } & \text { pevut }\end{array}$

